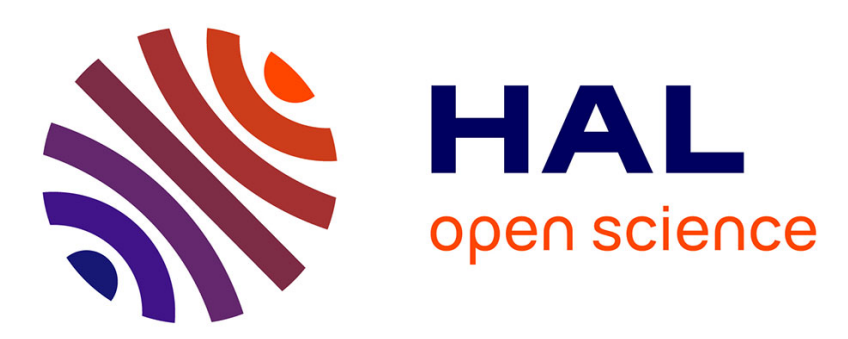

\title{
Taxonomic elements on Uropoda gressitti Hirschmann, 1972 from South Georgia (Acari: Uropodina: Uropodidae)
}

\author{
J. Kontschán
}

\section{- To cite this version:}

J. Kontschán. Taxonomic elements on Uropoda gressitti Hirschmann, 1972 from South Georgia (Acari: Uropodina: Uropodidae). Acarologia, 2011, 51 (3), pp.303-310. 10.1051/acarologia/20112015 . hal01600034

\section{HAL Id: hal-01600034 \\ https://hal.science/hal-01600034}

Submitted on 2 Oct 2017

HAL is a multi-disciplinary open access archive for the deposit and dissemination of scientific research documents, whether they are published or not. The documents may come from teaching and research institutions in France or abroad, or from public or private research centers.
L'archive ouverte pluridisciplinaire HAL, est destinée au dépôt et à la diffusion de documents scientifiques de niveau recherche, publiés ou non, émanant des établissements d'enseignement et de recherche français ou étrangers, des laboratoires publics ou privés.

\section{(ㅇ)(1) $\$$}

Distributed under a Creative Commons Attribution - NonCommercial - NoDerivatives| 4.0 


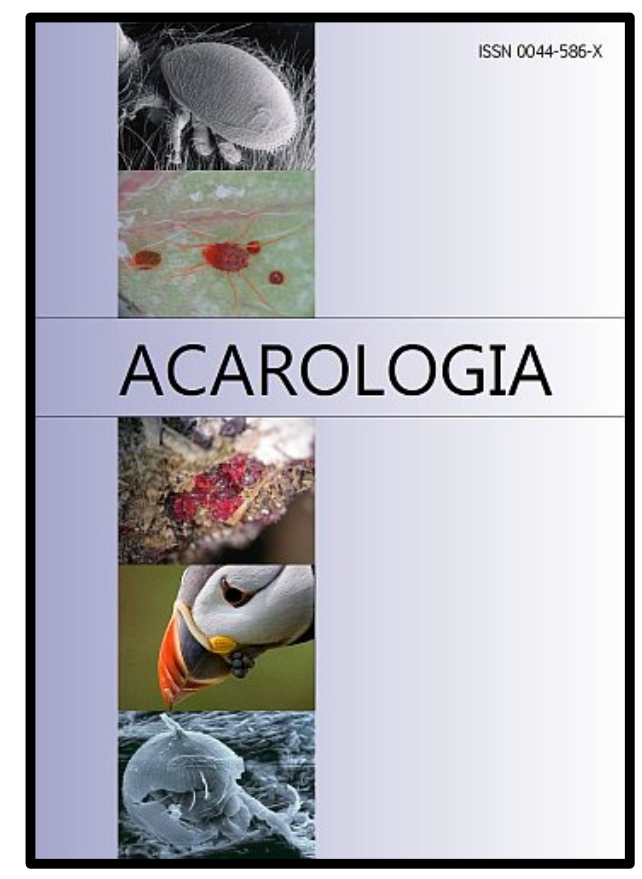

\section{ACAROLOGIA}

A quarterly journal of acarology, since 1959

Publishing on all aspects of the Acari

All information:

http://www1.montpellier.inra.fr/CBGP/acarologia/ acarologia@supagro.inra.fr

\section{OPEN ACCESS}

\section{Acarologia is proudly non-profit, with no page charges and free open access}

Please help us maintain this system by encouraging your institutes to subscribe to the print version of the journal and by sending us your high quality research on the Acari.

Subscriptions: Year 2017 (Volume 57): $380 €$ http://www1.montpellier.inra.fr/CBGP/acarologia/subscribe.php

Previous volumes (2010-2015): $250 € /$ year (4 issues)

Acarologia, CBGP, CS 30016, 34988 MONTFERRIER-sur-LEZ Cedex, France

The digitalization of Acarologia papers prior to 2000 was supported by Agropolis Fondation under the reference ID 1500-024 through the « Investissements d'avenir » programme

(Labex Agro: ANR-10-LABX-0001-01)
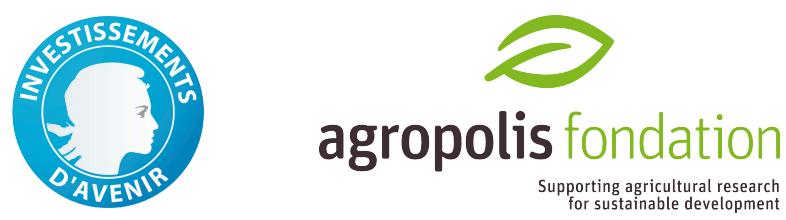

Acarologia is under free license and distributed under the terms of the

Creative Commons-BY-NC-ND which permits unrestricted non-commercial use, distribution, and reproduction in any medium, provided the original author and source are credited. 


\title{
TAXONOMIC ELEMENTS ON UROPODA GRESSITTI HIRSCHMANN, 1972 FROM SOUTH GEORGIA (ACARI: UROPODINA: UROPODIDAE)
}

\author{
Jenő KONTSCHÁN \\ (Received 17 February 2011; accepted 10 May 2011; published online 23 September 2011) \\ Systematic Zoology Research Group, Hungarian Academy of Sciences, Department of Zoology, Hungarian Natural History Museum H-1088 \\ Budapest, Baross u. 13. Hungary. kontscha@zool.nhmus.hu
}

ABSTRACT - Female, deutonymph, protonymph and larva of the species Uropoda gressitti Hirschmann, 1972 are described, based on specimens collected from South Georgia by the British Antarctic Survey in 1981. Original drawings of adult and immature stages are presented with a key to the Uropodina species of the Subantarctic region.

KEYWORDS - adult and immature stages; South-Georgia; Subantarctica

\section{INTRODUCTION}

Uropodina mites are small $(300-1200 \mu \mathrm{m})$, yellow or reddish-brown members of the soil fauna; they inhabit soil, leaf litter, moss, lichens and bark of tree. Several species live in association with other arthropods and vertebrates. More than two thousand species are known worldwide (Wiśniewski and Hirschmann 1993). The Antarctica is the most poorly studied region of the world, up to now only four Uropodina species are reported from this region.

The first two species found in the material collected during the German South-Polar Expedition (Possession Island), were described as Opisthope crozetensis Richters, 1907 and Piracarus crozetensis Richters, 1907 (Richters 1907). Later Hirschmann (1974) placed these two species into the genus Uropoda Latreille, 1806 resulting to the new combination Uropoda crozetensis (Richters, 1907), but Hirschmann (1974) needed to change the name of Piracarus crozetensis to Uropoda richtersi Hirschmann, 1974 to avoid homonymy.

Some years later Hirschmann (1972) observed soil material from the South Georgia and described two other new species: Uroobovella gressitti Hirschmann, 1972 and Uropoda gressitti Hirschmann, 1972. Unfortunately Hirschmann (1972) gave only a brief description of females of these species and he did not find the immature stages of the latter species.

In 2008, I spent two weeks in the Natural History Museum, in London, where I studied the unsorted soil samples of the Arachnida collection. I found several specimens of Uropoda gressitti Hirschmann, 1972 in the materials collected during the British Antarctic Survey, 1981. Females, deutonymphs, protonymphs and larvae of $U$. gressitti, were observed and their description and/or redescription is provided in the present paper. 


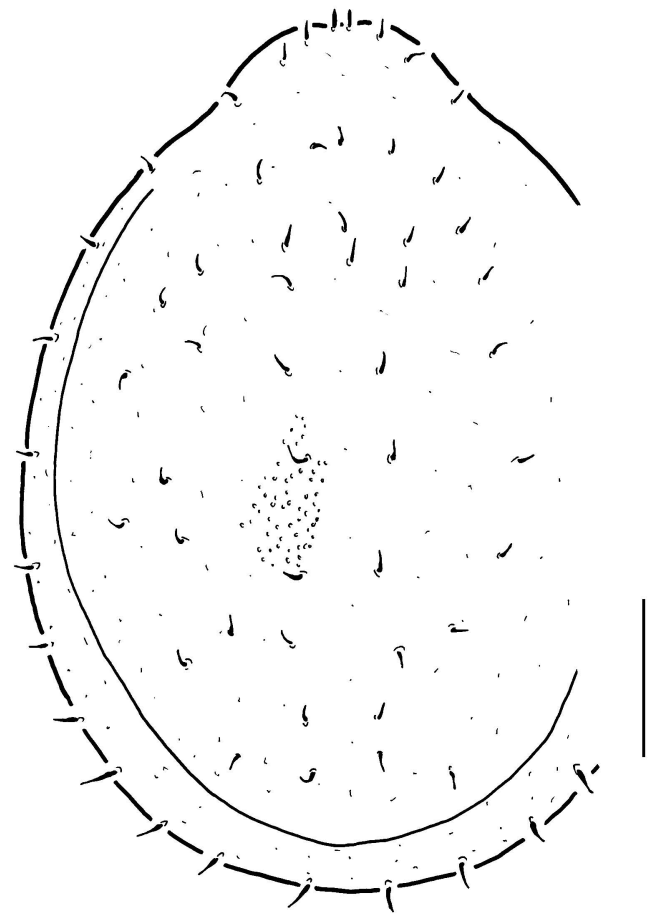

A

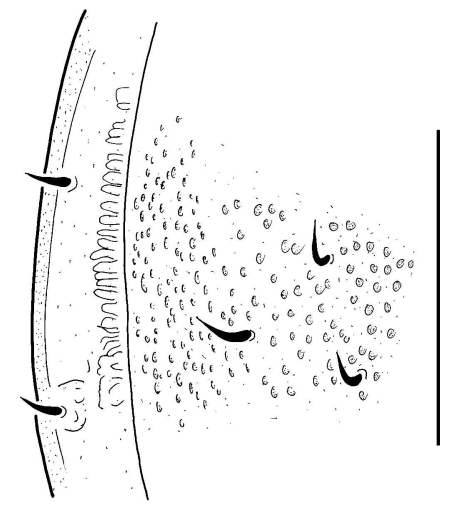

B

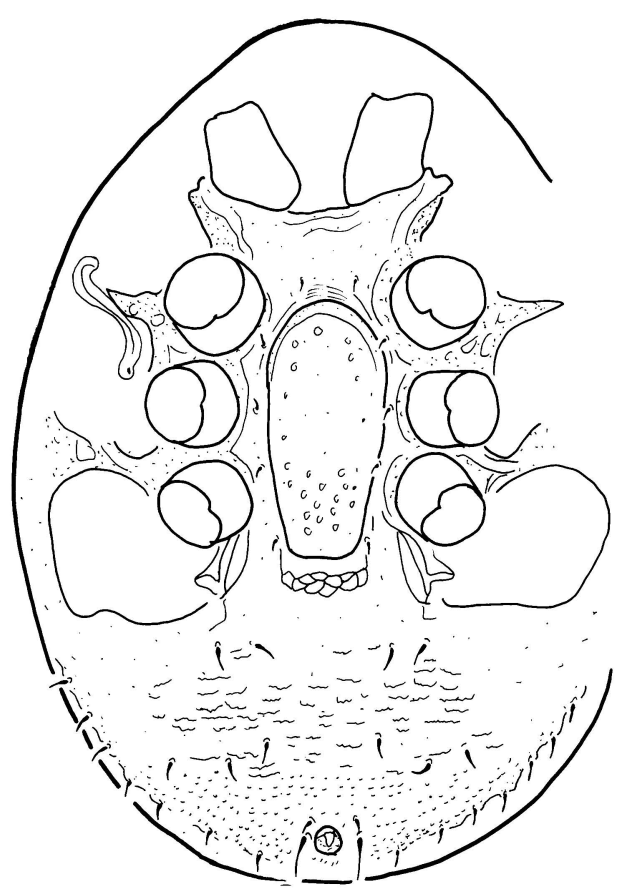

C

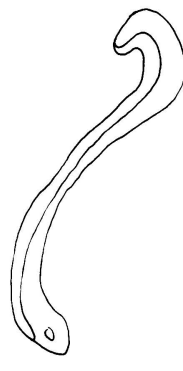

$\mathrm{D}$

FIGURE 1: Uropoda gressitti Hirschmann, 1972 (female): A - dorsal view; B - ornamentation and setae on dorsal shield; C - ventral view; $\mathrm{D}$ - peritreme. Scale bar $=100 \mu \mathrm{m}$.

\section{MATERIALS AND METHODS}

Specimens were cleared in lactic acid mounted on slides and later stored in alcohol. Drawings were made using a drawing tube at 16 and 40x magnification. All specimens examined are deposited in the Arachnida collection of the Natural History Museum, London (UK). Abbreviations: h1-h3, hypostomal setae, h4, capitular setae, St1-St5, sternal setae. Measurements are given in micrometers $(\mu \mathrm{m})$, width of idiosoma was taken at the level of the coxae IV. 

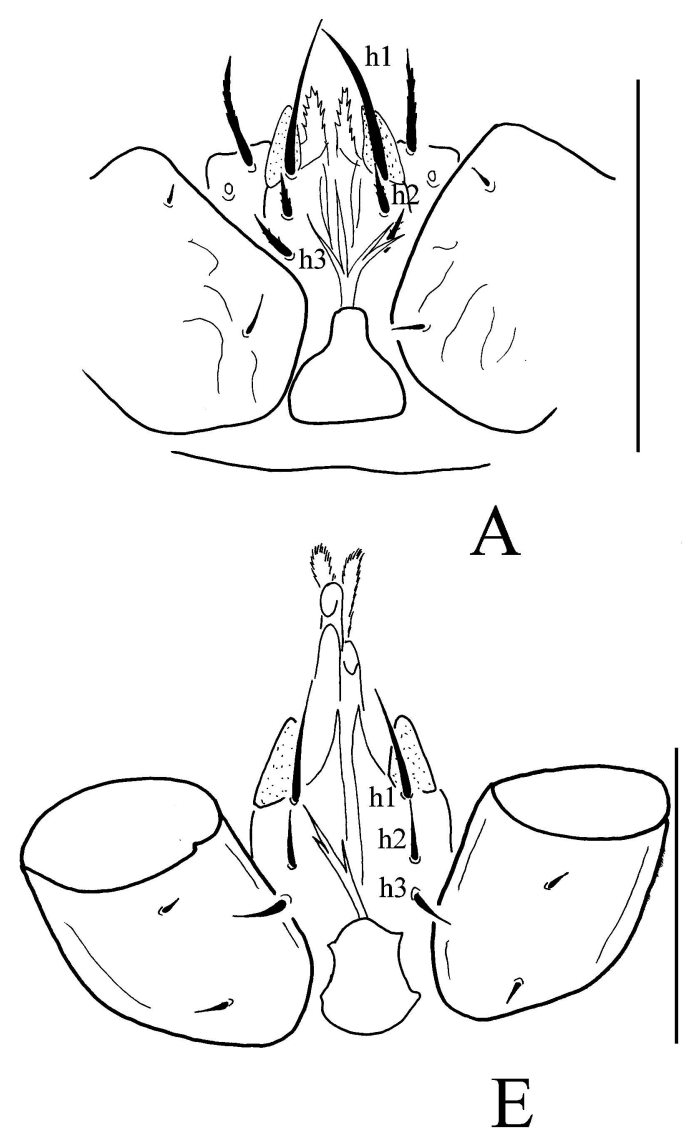
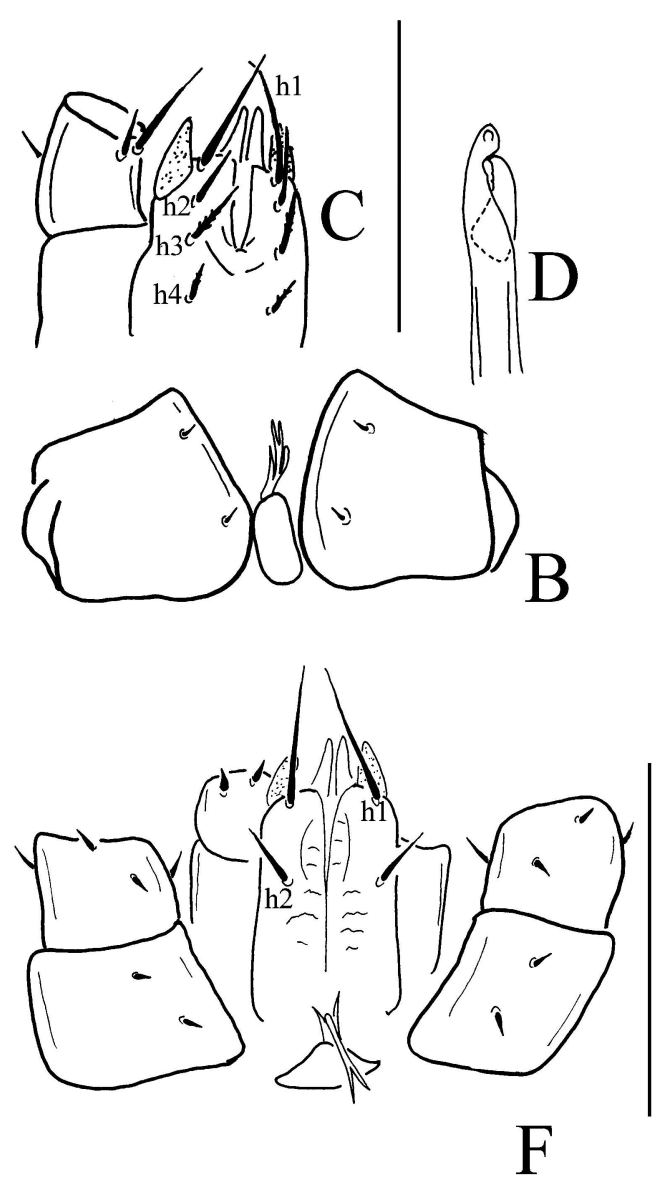

FIGURE 2: Uropoda gressitti Hirschmann, 1972: A - tritosternum, coxae I and ventral view of gnathosoma of female; B - tritosternum and coxae I of deutonymph; C - ventral view of gnathosoma of deutonymph; D - chelicerae of deutonymph; E - tritosternum, coxae I, apical part of chelicerae and ventral view of gnathosoma of protonymph; F - tritosternum, coxae and trochanter I, ventral view of gnathosoma of larva. Scale bar $=100 \mu \mathrm{m}$.

\section{RESULTS}

\section{Uropoda gressitti Hirschmann, 1972}

Uropoda (Phaulodinychus) gressitti Hirschmann 1972: 89-91, Figure 78.

Uropoda gressitti: Wiśniewski and Hirschmann 1993: 215., Wiśniewski 1993a: 286., Wiśniewski 1993b: 423.

Material examined - South Georgia, Maiviken, summer samples, "Block A", 01 January 1982: two females: A5/1b/2, two females: A2/1a/2, six females: $A 1 / 2 a / 2$, six females, one larva and one protonymph: $\mathrm{A} 3 / 2 \mathrm{a} / 2$, six females and one deutonymph: A1/1a/2. South Georgia, Maiviken, summer samples, "Block B", 11 January 1982: two females B1/2a/3; one female: B4/1a/3, one larva, three deutonymphs and seven females: $\mathrm{B} 6 / 1 \mathrm{a} / 3$ and two deutonymphs B3/1a/3.

\section{Female}

$\mathrm{n}=32$; Figures 1, 2: Length of idiosoma $530-560$ $\mu \mathrm{m}$, width $390-410 \mu \mathrm{m}$. Shape of idiosoma oval.

Dorsal idiosoma - (Figure 1A): Marginal and dorsal shields fused anteriorly. All dorsal setae smooth and needle-like (ca. $11-12 \mu \mathrm{m}$ ). Marginal setae similar to dorsal setae in shape and length. Dorsal shield covered by small alveolar pits (Figure $1 \mathrm{~B}$ ), this kind of ornamentation missing from marginal shield. 

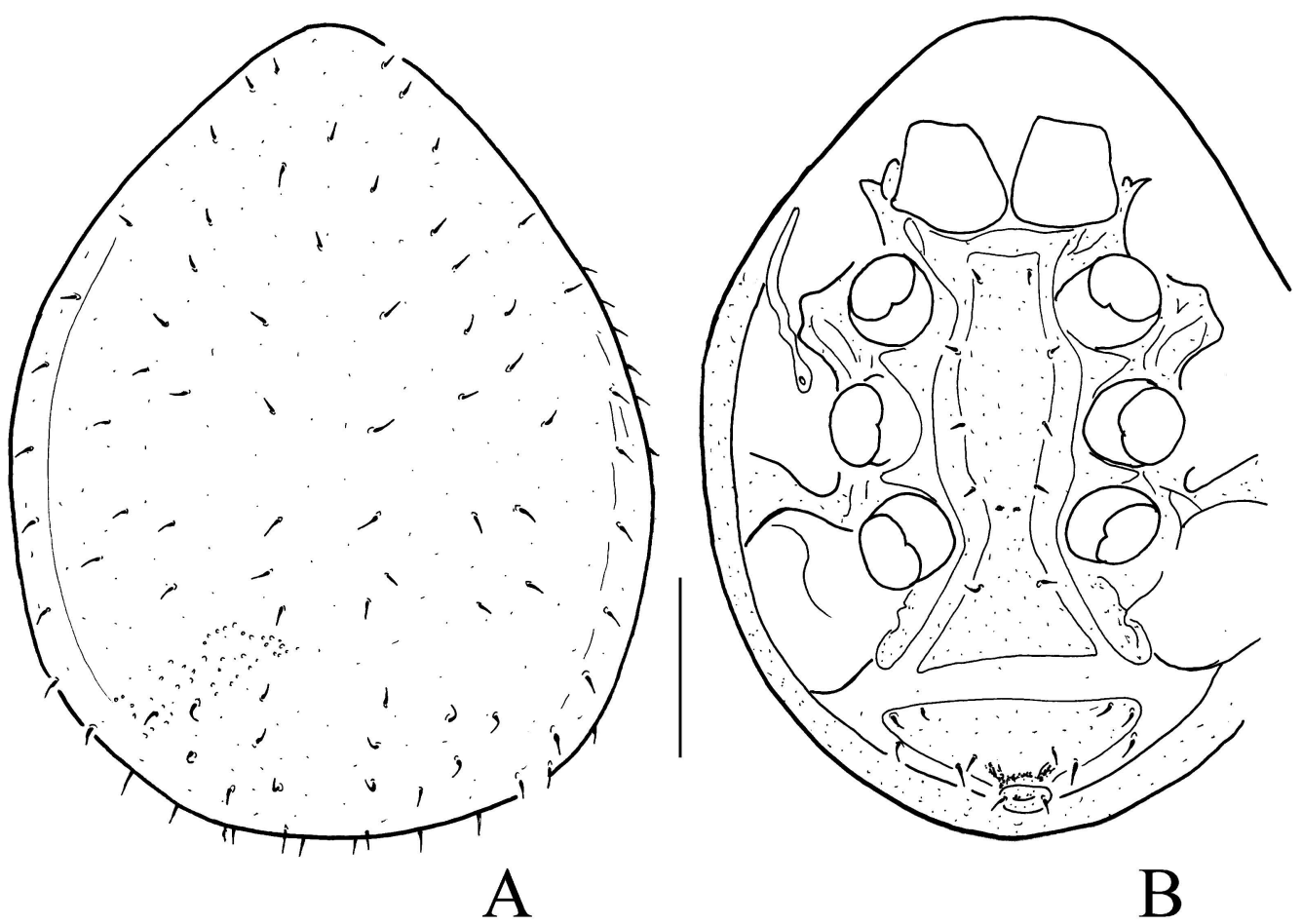

FIGURE 3: Uropoda gressitti Hirschmann, 1972 (deutonymph): A - dorsal view; B - ventral view. Scale bar $=100 \mu \mathrm{m}$.

Ventral idiosoma - (Figure 1C): Sternal setae short (ca. $6-7 \mu \mathrm{m})$, smooth and needle-like. St1 placed near anterior margin of genital shield, St2 near posterior margin of coxae II, St3 near central region of coxae III and St4 near anterior margin of coxae IV, St5 situated near posterior border of genital shield. Surface of sternal shield mostly smooth, but reticulate pattern present near the basis of genital shield. Ventral shield with small alveolar pits and undulate line ornamentation, all ventral setae smooth and needle-like (ca. $13-15 \mu \mathrm{m}$ ). Adanal setae setae smooth and needle-like, first pair of part adanal setae (ca. $7-8 \mu \mathrm{m}$ ) shorter than second pair (ca. $23-25 \mu \mathrm{m}$ ). Genital shield linguliform, without process and with oval pits. Genital shield placed between coxae II and IV.

Peritremes S-shaped - (Figure 1D).

Tritosternum - (Figure 2A) with wide basis, tritosternal laciniae divided into four smooth branches.
Gnathosoma - (Figure 2A): Corniculi horn-like, internal malae serrate. Hypostomal setae h1 long (ca. $43 \mu \mathrm{m}$ ) and smooth, h2 (ca. $10 \mu \mathrm{m})$ serrate, h3 similar to h2 in length and shape, h4 two times shorter than $\mathrm{h} 3$ their margin serrated (not illustrated in Figure 2A). Fixed digit of chelicerae longer than movable digit and bearing a single tooth. Cheliceral internal sclerotised node absent. Trochanter of palp bearing two serrated setae on ventral part. Epistome with pilose margin and with two apical branches.

Legs - Bearing smooth and simple setae, the first leg with claws.

\section{Deutonymph}

$\mathrm{n}=6$; Figure 3: Length of idiosoma $440-460 \mu \mathrm{m}$, width $340-350 \mu \mathrm{m}$. Shape of idiosoma oval.

Dorsal idiosoma - (Figure 3A): Dorsal setae and ornamentation similar to that of female.

Ventral idiosoma - (Figure 3B): Sternal shield without ornamentation. Sternal setae smooth and 


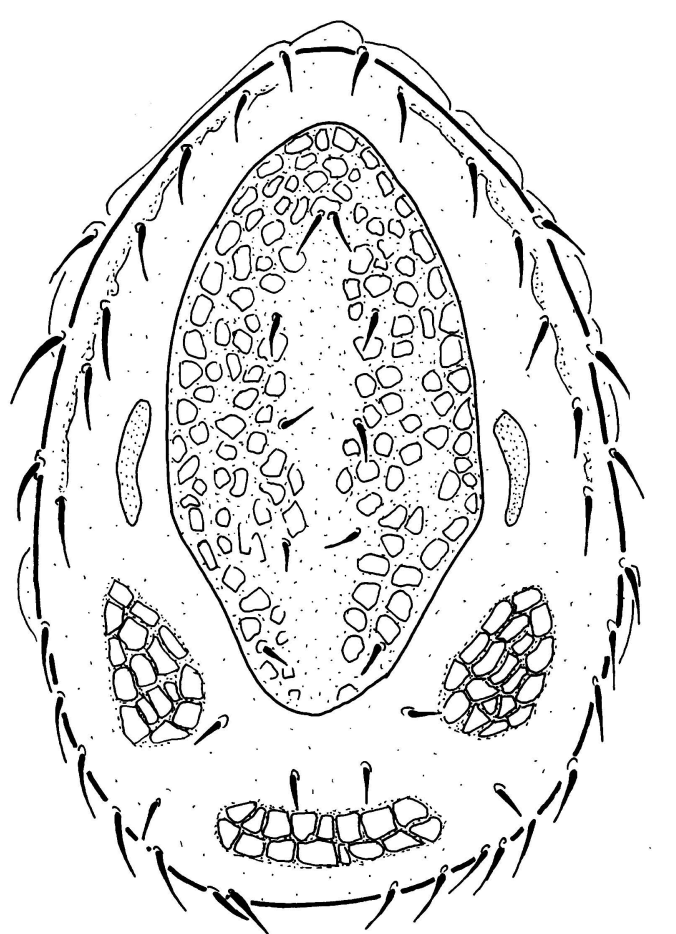

A

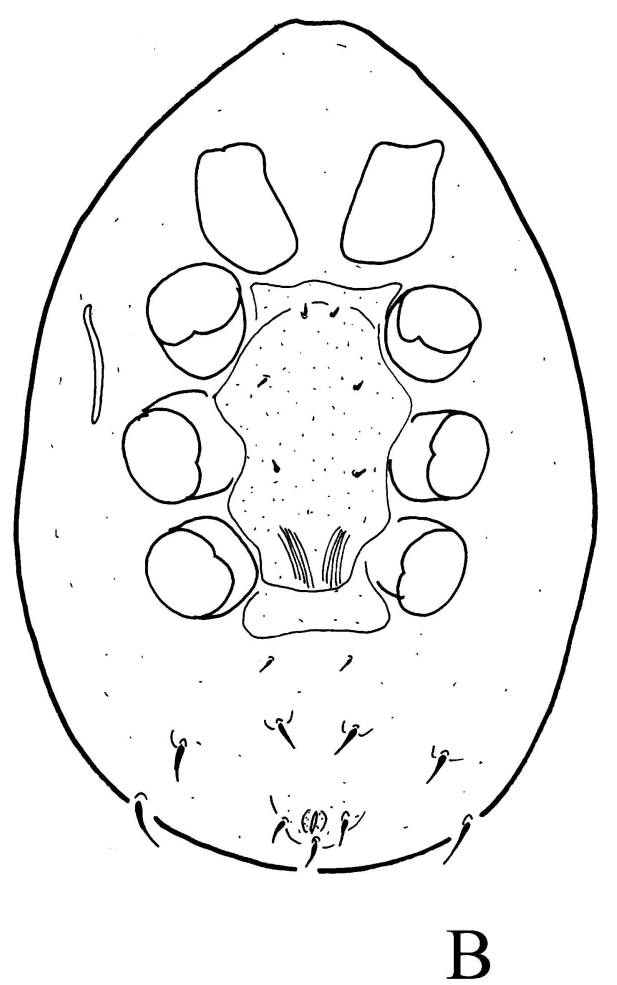

FIGURE 4: Uropoda gressitti Hirschmann, 1972 (protonymph): A - dorsal view; B - ventral view. Scale bar $=100 \mu \mathrm{m}$.

needle-like (ca. $7-8 \mu \mathrm{m}$ ), St1 placed on level of anterior margin of coxae II, St2 on level of posterior margin of coxae II, St3 on level of central region of coxae III, St4 on level of anterior margin of coxae III, St5 on level of posterior margin of coxae IV. Ventrianal shield without ornamentation and bearing four pairs of smooth and needle-like setae (ca. 10-11 $\mu \mathrm{m}$ ). Only one pair smooth and needle-like adanal setae (ca. $8-9 \mu \mathrm{m}$ ) present. Tritosternum with narrow basis, its laciniae smooth and divided into four branches (Figure 2B).

Gnathosoma - (Figure 2C): Corniculi horn-like, internal malae smooth. Hypostomal setae h1 long (ca. $40 \mu \mathrm{m}$ ) and smooth, h2 smooth (ca. $17 \mu \mathrm{m}$ ), $\mathrm{h} 3$ as long as h2 but their margins serrate, h4 marginally serrate (ca. $11 \mu \mathrm{m})$. Chelicerae similar to that of female (Figure 2D). Trochanter of palp bearing two smooth setae on ventral part. Epistome similar to that of female.

\section{Protonymph}

$\mathrm{n}=1$; Figure 4: Length of idiosoma $340 \mu \mathrm{m}$, width $270 \mu \mathrm{m}$. Shape of idiosoma oval.

Dorsal idiosoma - (Figure 4A): Podonotal, pygidial and two bigger, lateral shields covered by irregular pits, in the contrary surface of two smaller lateral shields smooth. Podonotal shield with five pairs of smooth and needle-like setae (ca. $18-20$ $\mu \mathrm{m})$. Other setae on dorsal idiosoma smooth and needle-like (ca. $15-17 \mu \mathrm{m}$ on central area and ca. $29-33 \mu \mathrm{m}$ near margins of idiosoma).

Ventral idiosoma - (Figure 4B): Sternal shield without ornamentation. Sternal setae smooth and needle-like (ca. $5-6 \mu \mathrm{m}$ ), St1 placed on level of ventral region of coxae II, St2 on level of posterior margin of coxae II, St 3 on level of posterior margin of coxae III, St 4 and St 5 absent. One pair of shorter (ca. $7-8 \mu \mathrm{m}$ ) and two pairs of longer (ca. $12-13$ $\mu \mathrm{m})$ (which placed on small protuberances), smooth 


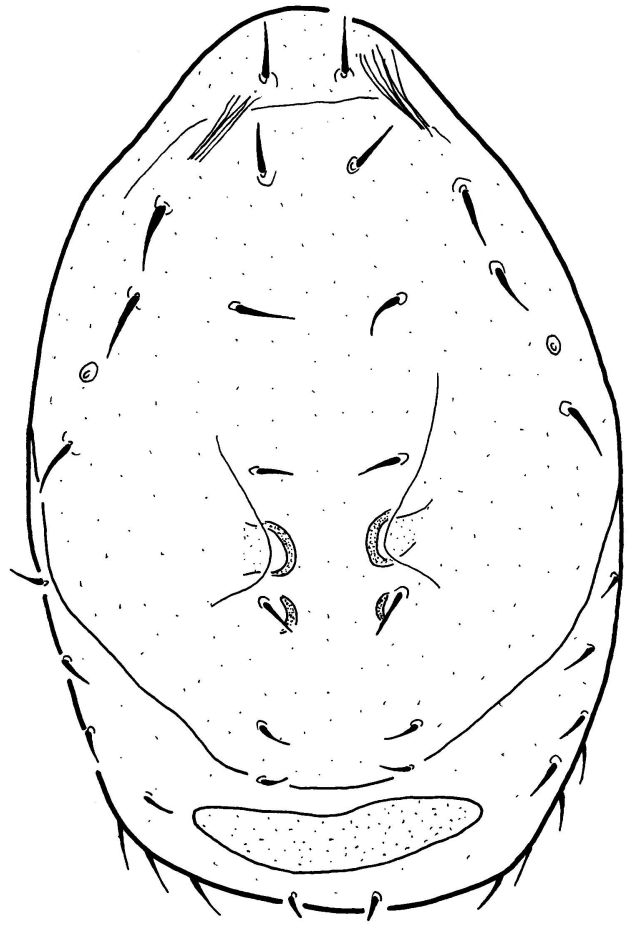

A

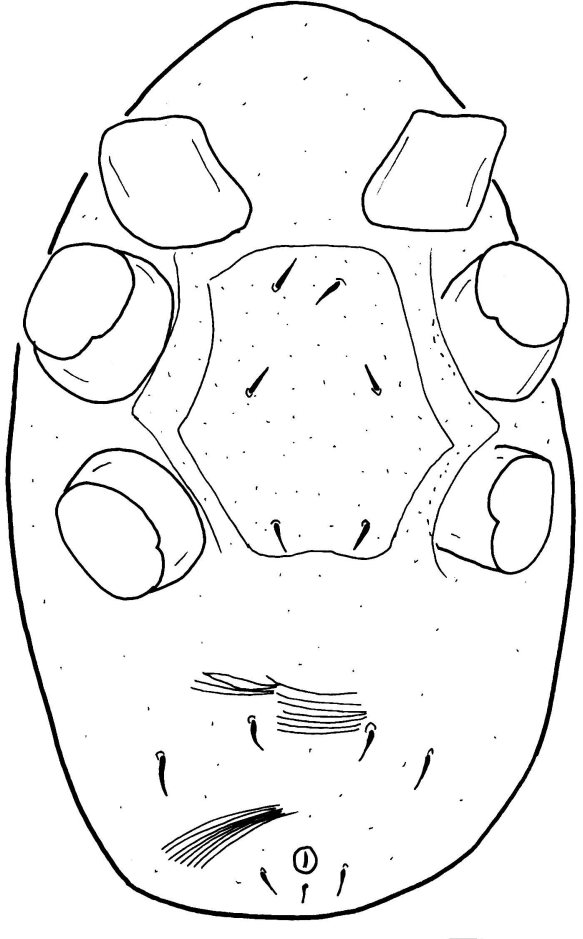

B

FIGURE 5: Uropoda gressitti Hirschmann, 1972 (larva): A - dorsal view; B - ventral view. Scale bar $=100 \mu \mathrm{m}$.

and needle-like ventral setae present on membranous cuticle. Anal shield with one pair of adanal setae (ca. $11-12 \mu \mathrm{m}$ ) and one postanal seta (ca. 12 $\mu \mathrm{m})$.

Tritosternum with narrow basis, its laciniae smooth and divided into three branches (Figure 2E).

Gnathosoma - (Figure 2E): Corniculi horn-like, internal malae smooth. Hypostomal setae h1 long (ca. $38 \mu \mathrm{m}$ ) and smooth, h2 ca. $13 \mu \mathrm{m}$ and smooth, h3 similar in shape and length to h2, h4 not clearly visible covered by coxae I. Chelicerae with longer fixed digit. Epistome similar to that of female.

\section{Larva}

$\mathrm{n}=2$; Figure 5: Length of idiosoma $270-310 \mu \mathrm{m}$, width $180-210 \mu \mathrm{m}$. Shape of idiosoma oval.

Dorsal idiosoma - (Figure 5A): Podonotal and pygidial shields present, lateral shields absent.
Podonotal and pygidial shields smooth, podonotal shield bearing two pairs of well sclerotised Cshaped humps. Podonotal shield with 11 pairs of smooth and needle-like setae (ca. $11-14 \mu \mathrm{m}$ ). Other setae on dorsal idiosoma smooth and needle-like (ca. $9 \mu \mathrm{m}$ ).

Ventral idiosoma - (Figure 5B): Sternal shield without ornamentation. Sternal setae smooth and needle-like (ca. $9-10 \mu \mathrm{m}$ ), St1 placed on level of anterior margin of coxae II, St2 on level of posterior margin of coxae II, St3 on level of posterior margin of sternal shield. St 4 and St 5 absent. One pair of smooth and needle-like ventral setae present on membranous cuticle (ca. $9-10 \mu \mathrm{m}$ ). One pair of adanal setae (ca. $10 \mu \mathrm{m}$ ) and one postanal seta (ca. $9 \mu \mathrm{m}$ ) present near anal opening on membranous cuticle.

Tritosternum with wide basis, its laciniae smooth and divided into four branches (Fig. 2F). 
Gnathosoma - (Figure 2F): Corniculi horn-like, internal malae smooth. Hypostomal setae h1 long (ca. $39 \mu \mathrm{m}$ ) and smooth, h2 (ca. $15 \mu \mathrm{m}$ ) smooth.

Occurrences - The specimens were found in South Georgia: Maiviken, Bay of Isles, Prince Olaf Harbour and West Bay.

\section{CONCLUSION}

Hirschmann (1972) described this species based on females (the number of the studied specimens is not given in Hirschmann's original description) and the description comprises only a few sentences; several characters (epistome, tritosternum, etc.) are missing from the description. The present paper thus provides a complete description of this species based on more than 30 females; it also provides the description of immature stages. Specimens presently examined are shorter in length than the specimens described by Hirschmann (1972) $(570 \mu \mathrm{m}$ long and $450 \mu \mathrm{m}$ wide), however any other significant differences was found in the studied specimens. During my investigation I found only the larvae, nymphs and females, hence I suggest this species could be parthenogenetic, which is typical for soil inhabiting species, forming low-density populations, especially in temperate and cool zones (Błoszyk et al. 2004). Hirschmann (1972) found this species in moss and lichen, similar to the newly collected specimens, which were caught in moist moss. To help Uropodina species identification from Subantarctic region, we proposed a key including four species. The other three Uropodina species known from this region are as follows:

Uropoda crozetensis (Richters, 1907) Opisthope crozetensis Richters, 1907: 284-285. Figures 10-13, on table 18 and Figures 24-26 on table 19. Uropoda crozetensis: Wiśniewski and Hirschmann 1993: 200., Wiśniewski 1993a: 286., Wiśniewski 1993b: 425. Distribution: Possession Islands.

Uropoda richtersi Hirschmann, 1974 Piracarus crozetensis Richters, 1907: 285-286. Figures 49 on table 18 and Figures $27-29$ on table 19. Uropoda richtersi Hirschmann, 1974: 36-38. Uropoda richtersi: Wiśniewski and Hirschmann 1993: 206.,
Wiśniewski 1993a: 286., Wiśniewski 1993b: 424. Distribution: Possession Islands.

Notes to Richters' species: Richters (1907) found every immature stage and both sexes of these two species. Unfortunately Richters (1907) illustrated the dorsal and ventral idiosoma of these species in photos, several characters (e.g. gnathosoma, etc) are not presented in the figures, hence the identification of these species on the basis of Richters's (1907) illustrations is very problematic.

Uroobovella gressitti Hirschmann, 1972 Uroobovella gressitti Hirschmann, 1972: 111-112. Figures 86. Uroobovella gressitti: Wiśniewski and Hirschmann 1993: 167., Wiśniewski 1993a: 286., Wiśniewski 1993b: 415. Distribution: South Georgia.

\section{Key to the females of Uropodina species of Subantarctic region}

1. Idiosoma oblong, setae $\mathrm{j} 1$ pilose, chelicerae with internal scletotised node........ Uroobovella gressitti — Idiosoma oval, setae j1 smooth, chelicerae without nodes ............................ 2

2. Dorsal and ventral idiosoma bearing large alveolar pits ...................... Uropoda richtersi — Dorsal idiosoma bearing small alveolar pits ... 3

3. Genital shield of female smooth .Uropoda crozetensis — Genital shield of female with alveolar ornamentation ....................... Uropoda gressitti

\section{ACKNOWLEDGEMENTS.}

I would like to thank Mr. Zsolt Ujvári for his valuable comments on the manuscript. I also would like to thank Dr Anne Baker and Mrs Janet Beccaloni for their kind hospitality during my study in London. I am grateful to Helen Peat to information about the collection localities. 


\section{REFERENCES}

Błoszyk, J., Adamski, Z., Napierala, A., Dylewska, M. 2004 - Parthenogenesis as a life strategy among mites of the suborder Uropodina (Acari: Mesostigmata) Can. J. Zool. 82(9): 1503-1511.

Hirschmann, W. 1972 - Gangsystematik der Parasitiformes Teil 123. Teilgänge, Stadien von 21 neuen Uropoda (Phaulodinychus)-Arten (Uropodini, Uropodinae) - Acarol. Schrift Vergleich Milbenk. 18:79-92.

Hirschmann, W. 1974 - Gangsystematik der Parasitiformes Teil 188. Die Uropodiden-Gattungen Opisthope und Piracarus Richters 1907 - eine gangsystematische Vorstudie - Acarol. Schrift Vergleich Milbenk. 20: 3638.

Richters, F. 1907 - Die Fauna der Moosrasen des Gausgerbs und einiger Südlicher Inseln. VIII. Milben Deutsche Südpolar-Expedition, 1901-1903. 9, Zoology 1: 278-302.

Wiśniewski, J. 1993a - Gangsystematik der Parasitiformes Teil 549. Die Uropodiden der Erde nach Zoo- geographischen Regionen und Subregionen geordnet (Mit Angabe der Lande) - Acarol. Schrift Vergleich Milbenk. 40: 221-291.

Wiśniewski, J. 1993b - Alphabetisches Verzeichnis der Uropodiden (Gattungen, Arten, Synonyma) - Acarol. Schrift Vergleich Milbenk. 40: 371-429.

Wiśniewski, J., Hirschmann, W. 1993 - Gangsystematik der Parasitiformes Teil 548. Katalog der Ganggattungen, Untergattungen, Gruppen und Arten der Uropodiden der Erde - Acarol. Schrift Vergleich Milbenk. 40: 1-220.

\section{COPYRIGHT}

$((c)$ EY-Nc-ND Kontschán. Acarologia is under free license. This open-access article is distributed under the terms of the Creative Commons-BY-NC-ND which permits unrestricted non-commercial use, distribution, and reproduction in any medium, provided the original author and source are credited. 